Goldschmidt 2021 Abstract

https://doi.org/10.7185/gold2021.7479

\section{Textural evidence of mantle-derived carbonate in composite granite- lamprophyre dykes associated with the formation of the Variscan Aigoual granite pluton, Massif Central, France.}

\author{
MARIANA WERLE ${ }^{1}$, GARY STEVENS ${ }^{1}$, JEAN-FRANÇOIS \\ MOYEN $^{2}$ AND OSCAR LAURENT ${ }^{3}$ \\ ${ }^{1}$ Stellenbosch University \\ ${ }^{2}$ Université Jean Monnet \\ ${ }^{3}$ CNRS-Géosciences Environnement Toulouse \\ Presenting Author: marianawerle96@gmail.com
}

The processes that control crustal growth by addition of new mantle derived material and the recycling of crustal components introduced into the mantle in convergent tectonic settings remain poorly understood aspects of convergent orogeny. In the southeastern Massif Central of France, along the northern margin of the late Variscan, Aigoual granite pluton, a sequence composite dykes appears to record an intimate interaction between a mantle derived lamprohyric magma and a weakly peraluminous granitic magma of likely crustal origin. Some dykes (typically $\mathrm{m}$ to $\mathrm{dm}$ in width) show apparent complete compositional gradation between these compositions. The most mafic compositions record a fine-grained, typically flow banded microporphyritic (plagioclase) groundmass, with larger clots of biotite and occasional K-feldspar phenocrysts (5 to $10 \mathrm{~mm}$ ). As compositions become more felsic, the size and abundance of $\mathrm{K}$ feldspar phenocrysts increases. The most $\mathrm{SiO}_{2}$-rich rocks are strongly porphyritic (quartz - up to $10 \mathrm{~mm}$; K-feldspar up to 50 $\mathrm{mm}$ ), with a microgranitic matrix. The pluton is characterized by similar compositions and textures to the granitic portions of the dykes, but is slightly more coarse-grained. We have identified carbonate (dolomite and calcite) in three different magmatic textural associations within mafic dykes: 1. Globular carbonate ocelli (Fig. $1 \mathrm{a}, \mathrm{d}, \mathrm{g}) ; 2$. Carbonate infilling intercrystaline spaces between euherdal quartz and euhedral and compositionally zoned plagioclase (Fig. 1 b, e, h); and 3. Carbonate in association with high Ti, Cr-rich biotite/phlogopite with the carbonate-biotite association pseudomorphing a prior blocky phase (Fig. 1 c, f, i). Collectively, we interpret these textures to reflect saturation of magmas produced by mixing between the lamprophyric and granitic components in carbonate, with the formation of an immiscible carbonate melt and the replacement of olivine and/or pyroxene phenocrysts by carbonate and biotite.

Figure $1 \mathrm{BSE}$ images and $\mathrm{x}$-ray maps illustrating the 3 types of carbonate. (a, d, g) Globular carbonate ocelli, possibly showing direction of ascent through the denser silicate magma; $(b, e, h)$ Interstitial carbonate between euhedral quartz, biotite and plagioclase. Plagioclase is characterized by normal zonation which is most clearly visible on the Si map; (c, f, i) Calcite and $\mathrm{Cr}$-rich phlogopite pseudomorph likely $\mathrm{Cr}$-rich clinopyroxene.

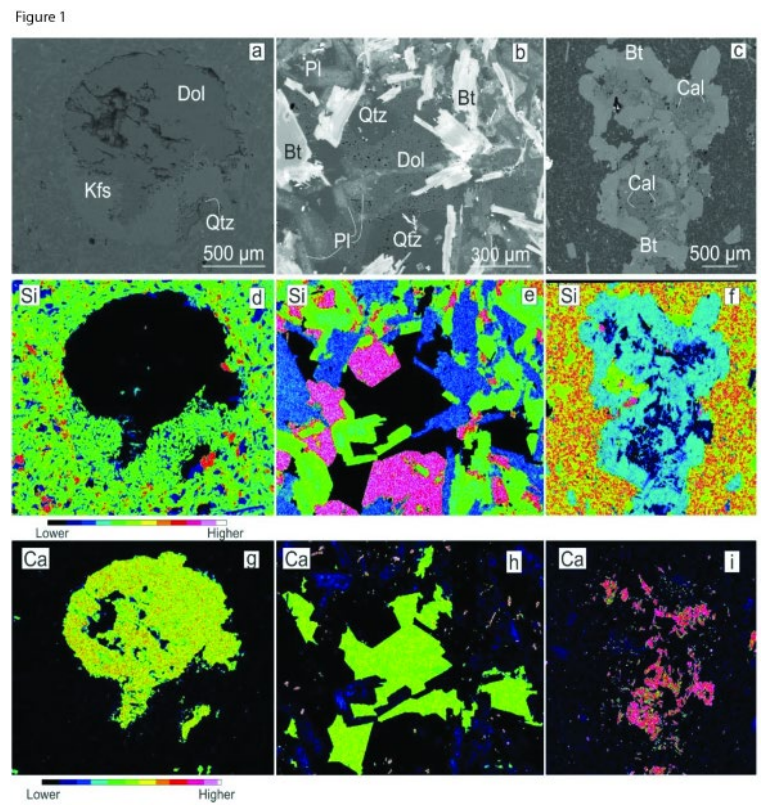

